\title{
An early view of Permo-Carboniferous glaciation and its implications, from Australia (1906)
}

\section{Introduction}

(Sir) Tannatt William Edgeworth David (1858-1934) is recognised as probably Australia's greatest geologist. Born at St Fagan's, near Cardiff, Wales, he graduated from Oxford University in 1880 and studied briefly at the Royal School of Mines, London. He was influenced by the geologists Joseph Prestwich and John Judd, his relative William Ussher, and the romantic author and artist John Ruskin, who had a significant interest in geology.

David's first research was carried out in South Wales, where he examined the evidence for Pleistocene glaciation, publishing three papers on this topic. In 1882, he was appointed to the Geological Survey of New South Wales, where he worked for nine years, carrying out important work on tin and coal mining. Of particular interest to the present paper was his meeting with Richard Oldham (1858-1942), who visited New South Wales in 1885 to compare the stratigraphy of the Australian coal measures with those of India. Oldham was familiar with the evidence for Late Palaeozoic glaciation in India, which had been studied by Henry Blanford, Thomas Oldham, and others.

In their brief time together, these geologists-together with David's chief Charles Wilkinson-examined some puzzling outcrops in the Permian rocks of the Hunter Valley, $150 \mathrm{~km}$ north of Sydney. Oldham was quick to identify features that were characteristic of glaciation, and David, with his experience of Pleistocene glaciation, recognised the significance of these occurrences and began recording the evidence - which proved to be widespread - in the large Sydney Basin of Permian-Triassic age, and later elsewhere, following hints of evidence of glaciation noted earlier in Victoria and South Australia.

David continued these studies when he was appointed to the chair of Geology at the University of Sydney in 1891, which he held until retirement in 1924, remaining at the University in an honorary capacity until his death in 1934. In 1887 he presented his first study of the Late Palaeozoic glaciation to an international audience, in a paper to the Geological Society of London, but it was received sceptically. He followed up in 1896 with another paper to the Society, this time presented in person, complete with large specimens of glaciated boulders. This paper was received with acclaim and succeeded in convincing many previous doubters.

An invitation to attend the Tenth International Geological Congress, held in Mexico in 1906, provided an ideal opportunity for David to present his ideas about the antipodean Late Palaeozoic glaciation, particularly to the geologists of the Americas, and also to European visitors. In the several years prior to the congress David had become involved in the study of a much earlier glaciation, recognised in particular by his South Australian colleague, Walter Howchin, who thought that that glaciation was Cambrian, but David suspected it was late Precambrian. On his way to the 1906 Congress, David collected evidence of both of the ancient glaciations, in the form of large striated boulders from South Australia, and he spoke of them as Late Palaeozoic and ?Early Cambrian at the meeting.

Instead of travelling direct to Mexico from Australia, David went west, via Europe, but en route he made a short visit to India to examine the evidence of the late Palaeozoic glaciation near Chanda, battling monsoonal rains and nearly drowning in his effort of seeing the famed glaciated pavements and the overlying glacial beds. His Congress paper was entitled 'Conditions of Climate at Different Geological Epochs, with Special Reference to Glacial Epochs', but he expanded this for publication in the Proceedings volume. While the Precambrian (Cambrian) evidence excited much interest, from the point of view of the study of the history of geology the material on the Late Palaeozoic glaciation has greater significance in relation to the later developments in the theory of continental drift. David's paper was probably the first to give, in any detail, evidence for the directions of movement and type of glaciation of the southern continents and India in a single paper, and accompanied by figures.

David was not to meet the South African geologist Alex du Toit until 1914, when they formed a firm friendship, and in the following twenty years (including a brief visit by David to South Africa in late 1925) they discussed many aspects of the continental drift hypothesis. The published paper, as with many of David's essays, was extensive. Consequently, only sections relevant to 'drift' theory have been chosen for reproduction here, omitting discussions of the Pleistocene, minimising the Precambrian material, and giving only a few of the details of evidence of the Late Palaeozoic from the various countries. The purpose is to highlight the discussion of the relations between the continents, and to show that, at this time David, could not see a really good explanation for the distribution of glaciation. That was to come a few years later. For further details, see Branagan (2005).

In what follows, the footnotes of David's paper have been converted to endnotes. His referencing method has, however, been retained, except that in the original he started renumbering the footnotes for each page. His inconsistent capitalization and his use of ${ }^{\circ} \mathrm{C}$ or deg. in different places in the paper have been followed. The pagination used in the offprints of the paper is given.

The paper also appeared as pp. 437-482 of Volume 1 of the Congress Proceedings.

\section{Conditions of climate at different geological epochs, with special reference to glacial epochs}

\section{By T. W. Edgeworth David, F.R.S}

Mexico: Imprenta y Fototipia de la Secretaria de Formento, Collejón de Betlemitas número 8, 1907

Geologorum Conventus, Mexico, 1906

[3] Evidence as to the climate of the past having been warmer than that of the present is perhaps on the whole not so clear and irrefutable as those kinds of evidence relating to past glaciations which demonstrate former colder climates. This statement is specially true as applied to evidences of past climatic changes in Australasia.

Until within comparatively recent years geologists believed that the earth, or at all events the Northern Hemisphere, had passed through one conspicuous glaciation,-that known as the Great Ice Age,-commencing in late Pliocene time and continuing through Pleistocene time, almost, if not quite, into the epoch known as the Recent.

It has, however [,] now been proved beyond dispute that in a period of time, commonly called the Permo-Carboniferous, the earth underwent a glaciation probably more severe than that to which the Northern Hemisphere was subjected during the Great Ice Age. Still more recently conclusive evidence has been adduced, chiefly by $\mathrm{Mr}$. Walter Howchin of Adelaide, and more recently by Mr. Bailey 
Willis, of the [4] existence of glacier ice in comparatively low latitudes in Lower Cambrian time, respectively, in Australia and in China. An earlier discovery by Dr. Rensch, at the Varanger Fjord in Norway, may also point to evidence of glaciation in Cambrian time. Dr. T. H. Holland, Director of the Geological Survey of India, has lately informed the author that he considers that the Blaini glacial beds of India are probably not Permo-Carboniferous in age as originally supposed, but perhaps Cambrian, or Pre-Cambrian. ... [Mr. A. W. Rogers] has also, as the author is verbally informed, discovered ... a band of glacial conglomerates in South Africa below the Table Mountain Sandstone. This he considers may be of Pre-Cambrian age. Professor J. W. Gregory has recorded the occurrence of similar beds-probably also Pre-Cambrian-at Spitzbergen. Mr. H. Y. L. Brown, the Government Geologist of South Australia, is of opinion that in that State there is strong evidence of the existence of glaciers, or at any rate of ice in some form close to the southern boundary of the tropics in South Australia.

The problem, therefore, of past glaciations is becoming more complex. In the opinion of the author the existence of glaciation at the following periods may now be considered proved, or partly proved, the glaciations being arranged in ascending order.

[5] (1). Partly proved. Pre-Cambrian glaciation.

(2). Proved. Lower Cambrian glaciation.

(3). Proved. Devonian glaciation.

(4). Proved. Permo-Carboniferous glaciation.

(5). Doubtful. Upper Cretaceous glaciation.

(6). Proved. Pleistocene glaciation.

The aut[h]or now proposes to state briefly the evidences for the glaciation older than the Pleistocene, then to refer briefly to special phenomena in Pleistocene glaciation, and lastly to suggest some possible causes for Ice Ages.

[The sections on Pre-Cambrian and Lower Cambrian are here omitted, as is the short section on the Devonian glaciation of South Africa, and possibly Norway, now generally discredited.]

\section{[15] 4. Permo-Carboniferous Glaciation}

Evidences of this most remarkable glacial epoch are widespread, and already well known in India, South Africa, and Australia [see Figure 1]. While quite recently evidences of an approximately contemporaneous glaciation have been adduced from Northern Argentina and southern Brazil.

\section{A. AUSTRALIA}

The evidences in Australia-perhaps the least known-will be described first.

It may be stated generally that many parts of Tasmania, and nearly all there [sic] areas of the Permo-carboniferous rocks along

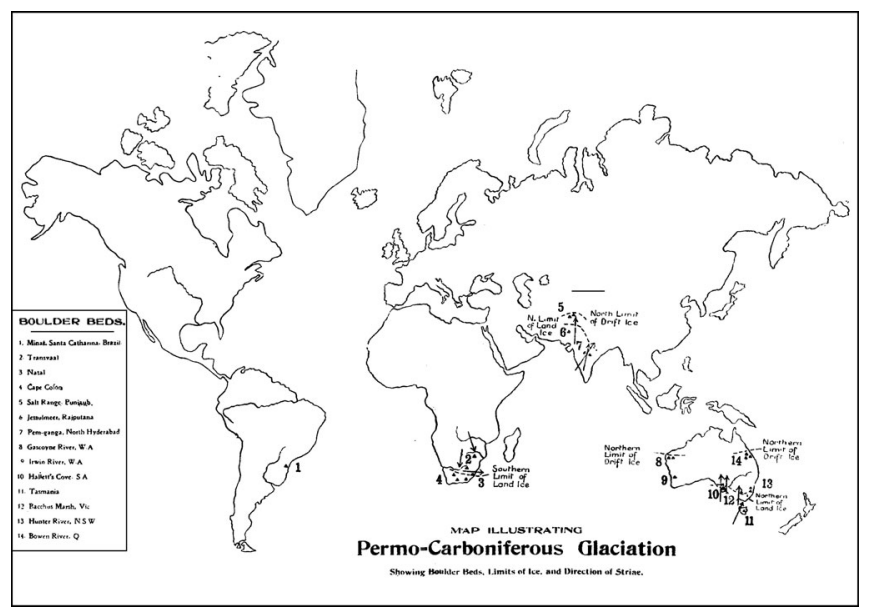

Figure 1. Map illustrating Permo-Carboniferous glaciations (T. W. E. David, 1906/1907, plate facing p. 14). the south coast of Australia, as well as along its east and west coasts as far north as the parallel of $23^{\circ}$ to $24^{\circ}$ South, show clear and conclusive evidence of some variety of contemporaneous ice action. The evidence takes the form of striated rock pavements [and boulders, see Figure 2,] and roches moutonnées. Occasional striated pavements in the boulder clays themselves, massive beds of till or boulder clay interstratified in themselves, but separated from one another by bands of sandstone, conglomerate, and shale. These intermediate strata between the glacial beds frequently exhibit strong proof of contemporaneous contortion. This was no doubt due to the pressure of glacier ice, to the grinding of icebergs, or to the melting away of subjacent sheets of ice and snow. Erratics also, of large size, are distributed here and there in the boulder clay from about the parallel of $44 \mathrm{deg}$. south latitude up to $36 \mathrm{deg}$. south latitude. Further north the erratics diminish somewhat in size, and are now found in association chiefly with strata of marine origin.

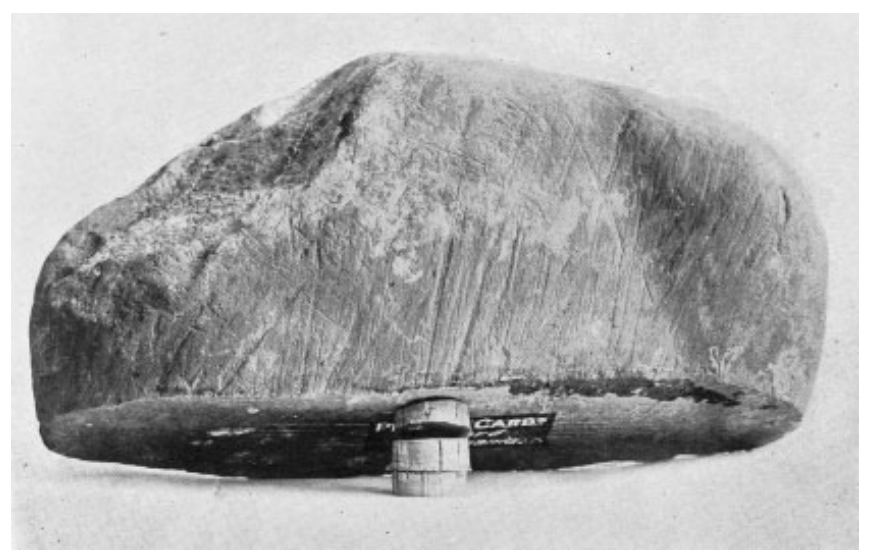

Figure 2 A glaciated boulder from the Permo-Carboniferous of Tasmania (T. W. E. David, 1906/1907, plate facing p. 20).

In a previous paper, it has been pointed out that at the [16] type area of Bacchus Marsh in Victoria there are at least two beds of till, possibly five or six, separated from one another by sedimentary strata other than till. These individual till beds may each point to a separate glaciation, the intercalated strata possibly marking the interglacial epoch. One fact stands out prominently in connection with this glacial group, viz. that in the area where the erratics are found in association with marine deposits a distinct set of Coal measures is interstratified with the erratic-bearing marine mudstones, namely the Greta Coal Measures...

The evidence is clear that ice was present in this region in Permo-carboniferous time in at least two forms. First, that of land ice, and secondly, that of floating ice or icebergs. The fact that the position of the groundmass of the boulder clay varies distinctly with that of the subjacent rock, between the parallels of 44 deg. and 36 deg. South, proves to the mind of the author that within these limits the glacial agent was land ice, in the form of confluent glaciers or of an ice sheet. The direction of movement of this ice has been determined at the various localities shown on Plate F. [See Figure 3.]

A reference to this Plate indicates that this land ice radiated apparently from some now eroded plateau to the south-west of Tasmania, and to the south-east of Adelaide. As shown in reports already published on the subject of the Bacchus Marsh glacial beds, it is evident that this ice sheet moved over a land surface of comparatively low relief, though eroded at the time into valleys at least 90 metres in depth. The ice on its path from south to north scooped out deep grooves, similar to those that one sees today in the Central Park of New York, in the hard Silurian quartzites, and graptolite slates. The direction of movement of the ice was such that it crossed some of these pre-existing valleys nearly at right angles, and in the process of its movement both the stoss-seite [thrust side] and the leeseite [lee side] of the valleys have been powerfully glaciated. It is inconceivable, in the opinion of the author, that any kind of ice but massive land ice could have accomplished such a work. This ice 


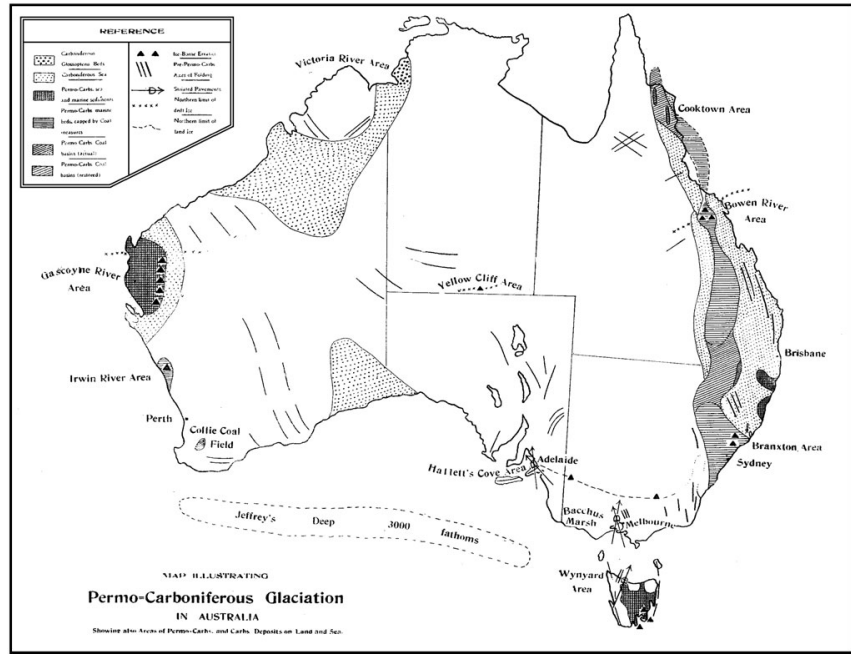

Figure 3. Permo-Carboniferous glaciation in Australia ( $T$. W. E. David, 1906/1907, plate facing p. 16). (The arrows with circles indicate glacial striations and their orientation. The supposed northern limit of land-ice in Victoria and South Australia is indicated by a dashed line. The northern limit of drift ice is indicated by the lines of small crosses north of the Bowen River in Queensland, the Gascoyne River in Western Australia, and in the Yellow Cliff Area of the Northern Territory. Black triangles indicate localities where ice-borne erratics are found. Lines on the map indicate various fold axes.)

came down to sea level in a field perhaps 1,600 kilometres in length from east to west, if not more. Near Adelaide the ice probably [17] came close to sea level about the parallel of $34 \mathrm{deg}$. South, while in New South Wales the northern limit of the glacier ice, following the trend of the present coast range, extended perhaps to about 33 1/2 deg. south. From this limit of the land ice icebergs in some numbers, as proved by the widely dispersed erratics, must have broken off, and have drifted along what is now the eastern coastal plain of Australia, as well as along its western plain. In the former case the floating ice reached the parallel of $21 \mathrm{deg}$. South latitude in the Bowen Coalfield, and in the latter case ... it extended as far north as the parallel of 24 deg. South.

...

[17] With regard to the erratics [as for the Lower Cambrian] ... they diminish in size with the latitude. Throughout the ... region, from the parallels of $44 \mathrm{deg}$. South to $21 \mathrm{deg}$. [south], and from longitude $115^{\circ}$ to $153^{\circ}$ the evidence of glacial action, while clear and irrefutable, is on such a grand scale that it needs to be actually seen in order to be properly appreciated.

[Then follows a section discussing the limited fossil evidence of climate change, and a brief mention of cold conditions suitable for the development of peat as the source of the coal measures.]

\section{B. INDIA}

[David refers to the publications documenting the evidence for Palaeozoic glaciation in India.]

Three chief areas may be referred to,-

1. Chanda.

2. Jaisalmer.

3. Salt Range.

In numbers 1 and 2 there is distinct evidence of land ice, and in 3 of floating ice.

[David considers the evidence for the Permo-carboniferous age of the beds and, after examination of material in India, suggests:]

[20] [I]t is probably only the Talchir beds, and perhaps the Karharbári beds, together with the marine fossiliferous beds of the
Salt Range characterised by Eurydesma cordatum, Conularia, \&c., which are of true permo-carboniferous age in the sense in which Australian geologists use that term....

The spot where the evidences of past glacial action are best seen is a little over 16 kilometres west-south-west of . . . Chanda . . . [where] the Pem limestone ... of . . older Palaeozoic age, [has been] ground down by ice action and strongly striated, grooved, and polished. These striae trend from about S. S. W. [21] to N.N.E. [the direction of ice movement]. . . [T] he boulders which occur in the Talchir mudstones, immediately overlying the Pem limestones . . . are found in situ at about 224 kilometres S.S.W. of Chanda. . . . The height above the sea of this remarkable striated pavement is only about 200 metres.

The boulder beds [cover] . . . an area of at least 260,000 to 750,000 square kilometres. . .

We have therefore, here [,] evidence of land ice on a large scale, ... having its source within at least 18 deg. of the Equator, ...

[T] here is no evidence to show that this Permo-Carboniferous peneplain was much higher than at present at the time of glaciation.

[Other Indian regions are similarly discussed.]

[22] The question next suggests itself[. F]rom what source did this remarkable mass of glacial ice, extending for nearly a thousand miles in a north and south direction, derive its snow in order to form the ice? It is, of course, very difficult to form even an approximate idea of the outline of the land, known as Gondwana [23] land, belonging to that period. It is generally assumed that the southern boundary of Gondwana land in permo-carboniferous time lay considerably to the south of Ceylon, and that the land embraced that part of the Indian Ocean now known as the Arabian Sea, as well as that area of it which lies in the direction of the Maldive Islands, the Great Chagos Bank, and Madagascar.

...

[David suggests that with such conditions the south-west monsoon could not operate and he postulates that the source of the snow must have been north of the Central Provinces of India, possibly Tibet.]

\section{RUSSIA}

\section{SOUTH AFRICA}

[24] [T]he evidences of past glaciation are of the nature of striated rock surfaces and boulder beds. The latter, known as the Dwyka conglomerate, are thickest in a southerly direction ... The extreme limits over which the Dwyka conglomerate has been proved to range are from latitude $25 \mathrm{deg}$. S to $32 \mathrm{deg}$. S, and from longitude about 23 deg. E to $32 \operatorname{deg} E$.

Fine examples of striated pavements underlie the Dwyka conglomerate. ... [25] [T] he ice movement . . . is proved to have been from the N.N.E. towards the S. S. W. [But] near Vreyheid [,] Molengraaff found that the direction of the ice movement was from N.W. towards the S.E.

... All these facts prove that the portion of South Africa in which the glaciated pavements have been observed was subject to the action of glacier ice, or a large ice sheet, which radiated outwards from some extensive central plateau in the Transvaal, Rhodesia, and the Orange River Colony. The height of this plateau above the sea is now about 1,500 metres.

From the information recently given the author by Mr. G. Lamplugh and Professor W. M. Davis ... the opinion may be formed that the South African ice sheet moved over the surface of a vast peneplain dissected to no great depth at the time of [26] the glaciation...

[26] ... [T]he assertion cannot be made in the case of the South African glaciation, that the glacier ice ever reached the sea and broke 
off there to form icebergs as happened in India and Australia at the same period.

[But David later postulated that it might have reached the sea near Cape Town.]

\section{[27] E. SOUTHERN BRAZIL}

The occurrence of a glacial conglomerate associated with Permo-carboniferous flora has recently been recorded by Dr. I. C. White from Southern Brazil. The locality is near Minas, Santa Catarina, in about latitude $281 / 2 \mathrm{deg}$. $S$.

[28] Dr. White states... [that] "In fact it appears that we have in Brazil a series of rocks which correlate closely with the Karroo system of South Africa, and that glacial conditions also existed in Brazil immediately preceding the deposition of the Coal measures there, during the epoch of the Orleans conglomerate, which corresponds to the Dwyka and Talchir conglomerates of Africa and India."

$$
\text { ... }
$$

A point of special interest in Dr. White's paper is the record of the association of plants with the glaciation ... [which] justifies the inference that the date of the glaciation either falls within the upper part of carboniferous time, or belongs to the lowest division of permo-carboniferous time.

$\cdots$

There can therefore be very little doubt as to the propriety of correlating provisionally, the Orleans conglomerate with the Dwyka, Talchir, and the Bacchus Marsh horizons.

[David then discusses the possible Cretaceous glaciation of Australia and the certain Pleistocene glaciation of the southern Hemisphere, following which he considers the possible causes of variations of climate that might bring about ice ages.]

[44] VARIATONS IN DISTRIBUTION OF LAND AND SEA HYPOTHESIS

There can be no doubt that at the present time climatic conditions are largely controlled by the above cause, which in turn regulates the direction of prevalent winds and ocean currents. For example, the greater cold of the Antarctic regions, as compared with the Arctic, at the present time is due, in the opinion of the author, chiefly to the fact of the development of a high mass of land near the South Pole, whereas the North Pole area is occupied chiefly by ocean. Were these geographically reversed conditions of temperature might be reversed also.

It is obvious that the great variations in climate at the present time of places situated in the same parallel of latitude depends chiefly on the local distribution of sea and land. A notable example of this is the temperate general climate of the British Islands as compared with that of Lower Canada. There can be no doubt therefore that variation in the distribution of sea and land must always have been a very important controlling factor on geological climate.

The question now suggests itself, is it possible by any theoretical arrangement of land and sea to bring about glaciations in subtropical areas close to sea level, as was the case in Permo-Carboniferous and Cambrian time?

We do not know yet enough about the distribution of land and water in Cambrian time to be able to reconstruct, with even remote approximation to accuracy, the lands and seas of that period. We do, however, know more about the biology and geography of the world in Permo-Carboniferous time. It has been assumed that a large land, Gondwana Land, extended more or less continuously from Australia to India, from India to Africa, and possibly from Africa to South America during part, [45] if not the whole of the Permo-Carboniferous period. It has been argued, under these conditions such a large mass of land would have checked the flow of equatorial currents into the Southern ocean, and would have helped to impound cold Arctic waters in the southern ocean; thus, the tendency under these conditions would have been to have made the equatorial regions warmer than at present, and the South Polar and temperate regions colder than at present. It was argued by Professor Gregory, at the York Meeting of the British Association for the Advancement of Science, that such a distribution of land and water would have been favourable for the Permo-Carboniferous glaciations. The assumption[,] however, was made that the gathering grounds of the ice fields in Australia, India, and South Africa were in the form of high mountain ranges. As already stated, such evidence as is available appears to the author not to support this view, and there is moreover conclusive evidence to show that these permo-carboniferous ice fields came down along widely extended fronts to sea level in parallels of latitude only 10 degrees polewards of the tropics. There can be no doubt that a land like the hypothetical Gondwana Land would have set up very strong monsoonal circulations of the atmosphere, the tendency being for aqueous vapour to be drawn inland by such a huge land mass, occupying at least the full width of the earth's surface between the tropics. Unless, however, as already stated, there were very high ranges in the path of the landward moving moisture laden currents there would be no precipitation at all, either as rain or snow, and if the mountains were high enough to cause a precipitation of snow, there is little more reason why those snowfields should come nearer to sea level than do the modern snowfields and glaciers of the Himalayas so far as relative distribution of land and sea is concerned.

In order therefore to explain the phenomena of past glaciations some other primary cause must probably be sought for, while, nevertheless, it may be admitted that variation in the distribution of land and sea was no doubt an important secondary controlling factor.

\section{[46] VARIATIONS IN SUN'S HEAT HYPOTHESIS}

\section{Concluding remarks}

Although David was prepared to accept the idea of Gondwanland, or at least discuss it, he was clearly puzzled about the contradiction between the implied need for a high mountain snow catchment for this huge landmass and the evidence of a lower surface with snow reaching to sea-level. Set as he was in the climate of 'permanent continents and oceans', David did his best to explain the paradox of the 'Permo-carboniferous' glaciation, as known in 1906, considering in the final pages of his paper a discussion of the Variations in Sun's Heat Hypothesis. By the 1920s, when he was in close contact with du Toit and Willem Waterschoot van der Gracht, and had studied Wegener's writings in detail, while his former student Lancelot Harrison was adamant that the drift theory was the only logical explanation for the distribution of southern hemisphere flora and fauna, perhaps David looked back at his 1906 map showing Permo-Carboniferous glaciation in India, South Africa, and Australia (Figure 1), where the explanation might be thought almost to have been staring him in the face. However, though he certainly mentioned it in passing in some of his lectures in Sydney, he never commented in detail in any publication at this time, and he focused on other aspects of geology in his last years.

\author{
David Branagan \\ Department of Geology and Geophysics \\ University of Sydney \\ Sydney 2006 \\ Australia \\ Email:dbranagan@mail.usydedu.au
}

